\title{
Instability of the environment at the end of the Eemian Interglacial as illustrated by isopollen maps of Poland
}

\author{
Mirosława KUPRYJANOWICZ ${ }^{1,{ }^{*},}$, Wojciech GRANOSZEWSKI ${ }^{2}$, Dorota NALEPKA ${ }^{3}$, \\ Irena Agnieszka PIDEK ${ }^{4}$, Adam WALANUS ${ }^{5}$, Zofia BALWIERZ ${ }^{6}$, Magdalena FIŁOC ${ }^{1}$, \\ Piotr KOŁACZEK ${ }^{7}$, Aleksandra MAJECKA ${ }^{8}$, Małgorzata MALKIEWICZ ${ }^{9}$, Małgorzata NITA ${ }^{10}$, \\ Bożena NORYŚKIEWICZ ${ }^{11}$ and Hanna WINTER ${ }^{12}$
}

1 University of Białystok, Department of Botany, Institute of Biology, Ciołkowskiego 1J, 15-425 Białystok, Poland

2 Polish Geological Institute - National Research Institute, Carpathian Branch, Skrzatów 1, 31-560 Kraków, Poland

3 Polish Academy of Sciences, Władysław Szafer Institute of Botany, Lubicz 46, 31-512 Kraków, Poland

4 Maria Skłodowska-Curie University, Department of Geoecology and Palaeogeography, Faculty of Earth Sciences and Spatial Management, Kraśnicka 2cd, 20-718 Lublin, Poland

5 AGH University of Science and Technology, Faculty of Geology, Geophysics and Environmental Protection, al. A. Mickiewicza 30, 30-059 Kraków, Poland

6 University of Łódź, Department of Geomorphology, Institute of Earth Sciences, Narutowicza 88, 90-139 Łódź, Poland

7 Adam Mickiewicz University, Department of Biogeography and Palaeoecology, Institute of Geoecology and Geoinformation, Dzięgielowa 27, 61-680 Poznań, Poland

8 University of Warsaw, Department of Climate Geology, Institute of Geology, Żwirki i Wigury 93, 02-089 Warszawa, Poland

9 University of Wrocław, Laboratory of Palaeobotany, Department of Stratigraphical Geology, Institute of Geological Sciences, Cybulskiego 30, 50-205 Wrocław, Poland

10 University of Silesia, Department of Fundamental Geology, Faculty of Earth Sciences, Będzińska 60, 41-200 Sosnowiec, Poland

11 Nicolaus Copernicus University, Department of Geomorphology and Palaeogeography of the Quaternary, Faculty of Earth Sciences, Gagarina 9, 87-100 Toruń, Poland

12 Polish Geological Institute - National Research Institute, Rakowicka 4, 00-975 Warszawa, Poland

Kupryjanowicz, M., Granoszewski, W., Nalepka, D., Pidek, I.A., Walanus, A., Balwierz, Z., Fiłoc, M., Kołaczek P., Majecka, A., Malkiewicz, M., Nita, M., Noryśkiewicz, M., Winter, H, H., 2016. Instability of the environment at the end of the Eemian Interglacial as illustrated by isopollen maps of Poland. Geological Quarterly, 60 (1): 225-237, doi: 10.7306/gq.1271

Many terrestrial pollen profiles from Poland (and a few pollen records from other parts of Central Europe) show the end of the last interglacial (Eemian, MIS 5e) to have been characterized by climatic and environmental instability. This is expressed by a strong, rapid cooling in the middle part of the pine phase ending this interglacial (E7 regional pollen assemblage zone), and then a re-warming at the very end of this phase, immediately before the transition to the glacial conditions of the last glaciation (Vistulian, Weichselian, MIS 5d). We have characterized the regional distribution of these climatic fluctuations in Poland on the basis of isopollen maps prepared for the Eemian Interglacial based on palynological data from 31 Polish pollen profiles. These maps show unequivocally that the intra-interglacial cooling at the end of the Eemian Interglacial was a transregional phenomenon, which was reflected very clearly by a temporary openness of vegetation across the whole of Poland. It was associated with a distinct decrease in pine forest areas and an increase in birch forests and open communities of cold steppe type with a domination of Artemisia. The pronounced climate and environment instability during the last phase of the Eemian Interglacial may be consistent with it being a natural phenomenon, characteristic of transitional stages. Taking into consideration the currently observed global warming, coinciding with a natural cooling trend, the study of such transitional stages is important for understanding the underlying processes of climate change.

Key words: palaeoclimate, intra-interglacial cooling, vegetation history, isopolles, pollen analysis.

\footnotetext{
*Corresponding author, e-mail: m.kupryjanowicz@uwb.edu.pl
} 


\section{INTRODUCTION}

The question of environmental stability during the Eemian Interglacial has long been discussed (Velichko et al., 1982, 2005; Fronval and Jansen, 1996; Litt et al., 1996; Kukla et al., 1997, 2002; Seidenkrantz and Knudsen, 1997; Saarnisto et al., 1999; Guiter et al., 2003; Klotz et al., 2003, 2004; Kühl and Litt, 2003; Seppä et al., 2008, and others). The discussions widened when a record of strong temperature fluctuations during the Eemian Interglacial was discovered in ice cores in Greenland (Anklin et al., 1993; Dansgaard et al., 1993; Grootes et al., 1993; GRIP, 1993). The results of the North Greenland Ice Core Project (2004) revealed, as one of the most important factors, abrupt climate warming about 115,000 years ago towards the end of the last interglacial, before glacial conditions were fully developed. The presence of strong fluctuations in climate in the final phase of the Eemian Interglacial was supported by pollen data from some European sites. These data come mostly from the long maar sequences in Southern Europe (e.g., Tzedakis et al., 1994). In Central and Eastern Europe such data are scarce (Müller, 1974; Beaulieu and Reille, 1989, 1992a, b; Mamakowa, 1989; Guiot et al., 1993; Field et al., 1994; Thouveny et al., 1994; Cheddadi et al., 1998; Granoszewski, 2003; Borisova et al., 2007; Kupryjanowicz, 2008; Boettger et al., 2009). In the Eemian sequence from Gröbern in Germany, the stable isotope data indicated a pronounced warming phase towards the very end of the interglacial, just before the transition to the glacial epoch (Boettger et al., 2009). A similar climatic oscillation is recorded in a few other profiles from Germany (e.g., Neumark-Nord - Eissmann, 2002, and Klinge - Striegler, 1986; Velichko et al., 2005; Novenko et al., 2008a) and some profiles from Russia (e.g., Ples - Borisova et al., 2007). Boettger et al. (2009) compiled profiles from Central and Eastern Europe, including the pollen record of climate instability at the end of the Eemian Interglacial. In this list, however, data from Polish profiles are missing. Our review of Polish palynological data on the Eemian Interglacial demonstrated that at least a dozen such sites existed in Poland (Fig. 1). In pollen record from these sites the abrupt cooling was recognized by us in the middle part of the E7 Pinus zone, which was the final phase of the last interglacial. This event is recorded there as a temporary decrease in pine frequency and a spreading of birch, and then also of open vegetation (Fig. 2). At the majority of these sites this cooling was not distinguished by the authors of the reports. Despite that, the palynological record is, in our opinion, unambiguous and fully justifies this distinction.

Our aim was to look into distribution of the pollen records of the Late Eemian climatic fluctuations in Poland. The best technique for such a regional synthesis of palynological data is the isopollen method. Isopolles are synchronous lines limiting areas with identical percentage shares of pollen from a specific plant taxon, linking points (sites), where the same share of pollen was recorded at a given time. The isopollen method was introduced by Szafer (1935) in his work on the postglacial history of vegetation in Poland. Later, this synthetic method for the presentation of pollen data was successfully used and developed in different countries (Sauremo, 1940; Firbas, 1949; Bertsch, 1953; Donner, 1963; Moe, 1970; Birks et al., 1975; Birks and Saarnisto, 1975; Davis and Webb, 1975; Davis, 1976; Bernabo and Webb, 1977; Huntley and Birks, 1983; Ralska-Jasiewiczowa, 1983; Webb et al., 1987). Recently, the role of the isopollen method has become even more significant with the development of databases, dedicated software and numerical methods (e.g., Ralska-Jasiewiczowa et al., 2004; Obidowicz et al., 2013; Wacnik et al., 2015).

The main objective of our investigation is to contribute to a better understanding of climatic variability during the terminal phase of the last interglacial by studying pollen profiles from Poland. It allows us to infer that the recognition of the climate changes in the declining part of the Eemian Interglacial enables the prediction of analogous natural changes that should have occurred in the late Holocene, and their separation from anthropogenic changes.

\section{MATERIAL AND METHODS}

\section{PALYNOSTRATIGRAPHY OF THE LATE EEMIAN IN POLAND}

Due to the lack of determination of the absolute age of the Eemian lacustrine and mire deposits, the horizons for which we drew isopollen maps are not time horizons, but they are biostratigraphical horizons, i.e. pollen horizons. The period under consideration includes the E7 Pinus regional pollen zone determined for Poland by Mamakowa (1989). It is the last (youngest, uppermost) pollen assemblage zone of the Eemian Interglacial. In this zone we distinguished five regional subzones (Fig. 2 and Table 1) based on features proposed by Kupryjanowicz (2008), who was the first to draw attention to the cold interglacial climatic oscillations in these Eemian pollen records. Isopollen maps for selected pollen taxa of trees (Pinus sylvestris t., Betula and Picea abies t.), shrubs (Juniperus communis), dwarf shrubs (Calluna) and the sum of herbaceous plants was prepared for each of these subzones. These plants were the main components of vegetation in the part analysed of the Eemian Interglacial. To demonstrate the difference in the pattern of isopolles (and thus in the regional diversity of vegetation) between a cold event within the pine zone and the first stadial of the Early Vistulian (Weichselian), we also created an isopollen map for the regional pollen zone representing this stadial (EV1)

SITES

Based both on Mamakowa's studies $(1989,2003)$ and on further original work from 2003-2014 we created the pollen database, which includes data from 184 sites where a complete pollen record for at least one zone of the Eemian Interglacial was registered (Kupryjanowicz et al., in print). The pollen record of the pine zone (E7 R PAZ) was recognized for as many as 112 of these sites. However, sections of profiles containing this record were studied very variously. Most of them are of low resolution, and therefore they do not contain a record of a cold event within the pine zone. This event was recognized at 31 sites (Fig. 3). Its location is shown both in Figure 1 and on isopollen maps presented in this paper (Fig. 4).

\section{CONSTRUCTION OF ISOPOLLEN MAPS}

The data required for isopollen maps of the Eemian Interglacial are stored in the POLPAL system (Walanus and Nalepka, 1999; Nalepka and Walanus, 2003; see also web page POLPAL). Most of the pollen tables that make up the Eemian database contain the raw data, i.e. pollen counts. Several tables contain percentages, because they were available only in this form. More than a dozen tables contain raw data, 


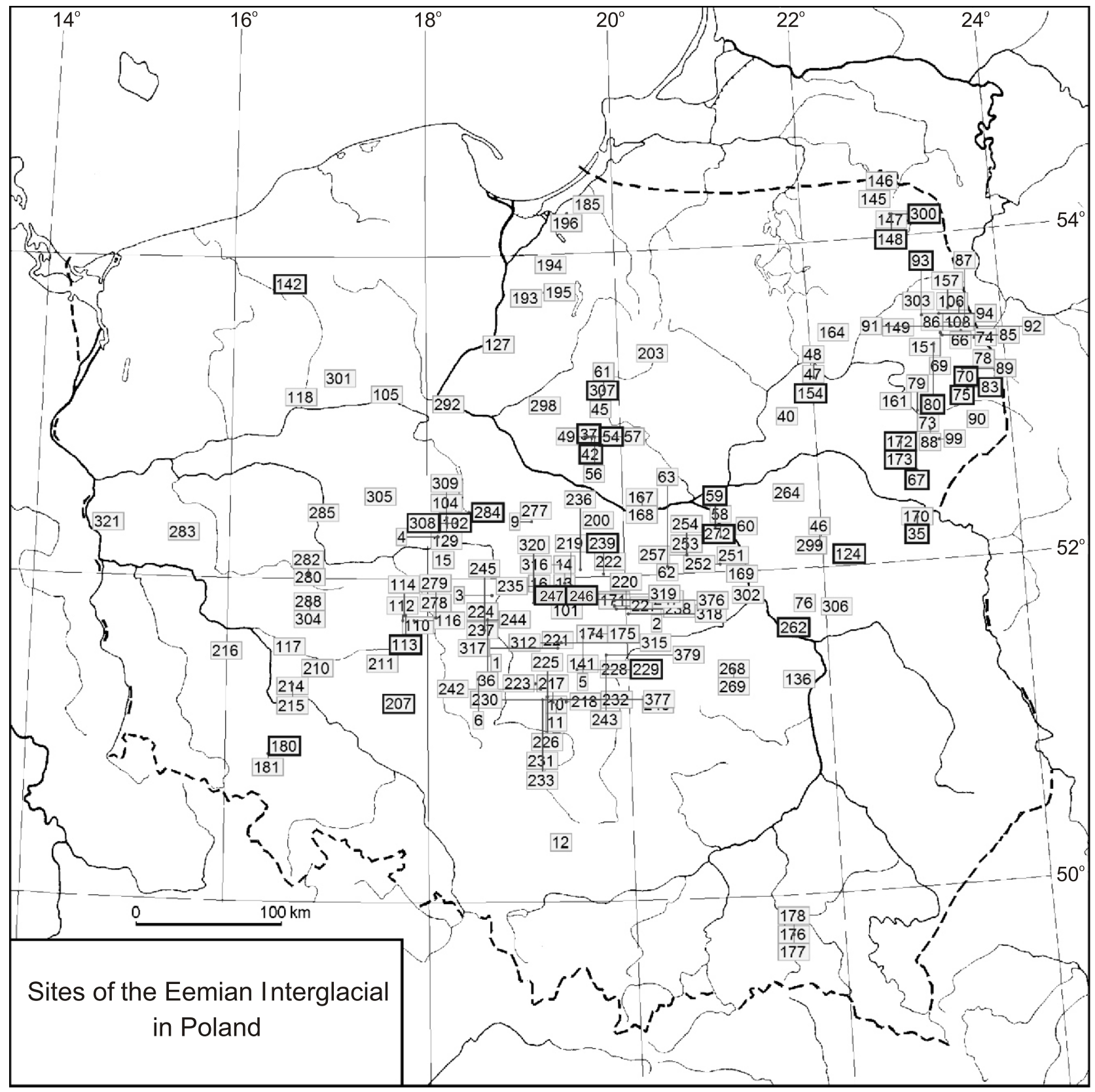

Fig. 1. Location of sites studied (sites with numbers in black squares; the numbers of sites according to the Eemian isopollen data base) on the background of other Polish localities of the Eemian Interglacial from isopollen data base (sites with numbers in grey)

35 - Horoszki Duże (Granoszewski, 2003), 37 - Babiec Piaseczny (Krupiński, 1995; Kotarbiński and Krupiński, 1995), 42 - Dąbrówki (Krupiński, 2005), 54 - Studzieniec (Krupiński, 2005), 59 - Warszawa-Wawrzyszew (Krupiński and Morawski, 1993); 67 - Choroszczewo (Kupryjanowicz, 2008), 70 - Dzierniakowo (Kupryjanowicz, 2008), 75 - Hieronimowo (Kupryjanowicz, 2008 ); 80 - Machnacz (Kupryjanowicz, 1991, 1994), 83 - Michałowo (Kupryjanowicz and Drzymulska, 2002), 93 - Solniki (Kupryjanowicz, 2008$), 102$ - Mikorzyn Starszy (Stankowski et al., 1999), 113 - Grudzielec (Malkiewicz, 2002), 124 - Wiśniew II (Pidek and Terpiłowski, 1993, 1995a, b), 142 Rzecino (Winter et al., 2008), 148 - Szwajcaria 1 (Borówko-Dłużakowa and Halicki, 1957), 154 - Konopki Leśne (Borówko-Dłużakowa and Halicki, 1957), 172 - Otapy I (Bitner, 1956), 173 - Otapy II (Bitner, 1956), 180 - Imbramowice (Mamakowa, 1989), 207 - Dziadowa Kłoda (Kuszell, 1998), 229 - Krzepczów 4 (Klatkowa, 1972), 239 - Skaratki (Chmielewski, 1961), 246 - Zgierz-Rudunki I (Jastrzębska-Mamełka, 1985), 247 - Zgierz-Rudunki II (Jastrzebska-Mamełka, 1985), 262 - Kletnia Stara (Janczyk-Kopikowa, 1986, 1987; Żarski, 1989), 272 Warszawa-Wola (Borówko-Dłużakowa, 1960), 284 - Ruszkówek (Janczyk-Kopikowa, 1997), 300 - Szwajcaria (Ber et al., 1998; Krupiński, 1998); 307 - Zieluń ZN.1.00 (Krupiński, 2005); 308 - Mikorzyn 1 (Stankowski et al., 1999, 2003; Stankowski and Nita, 2004) 


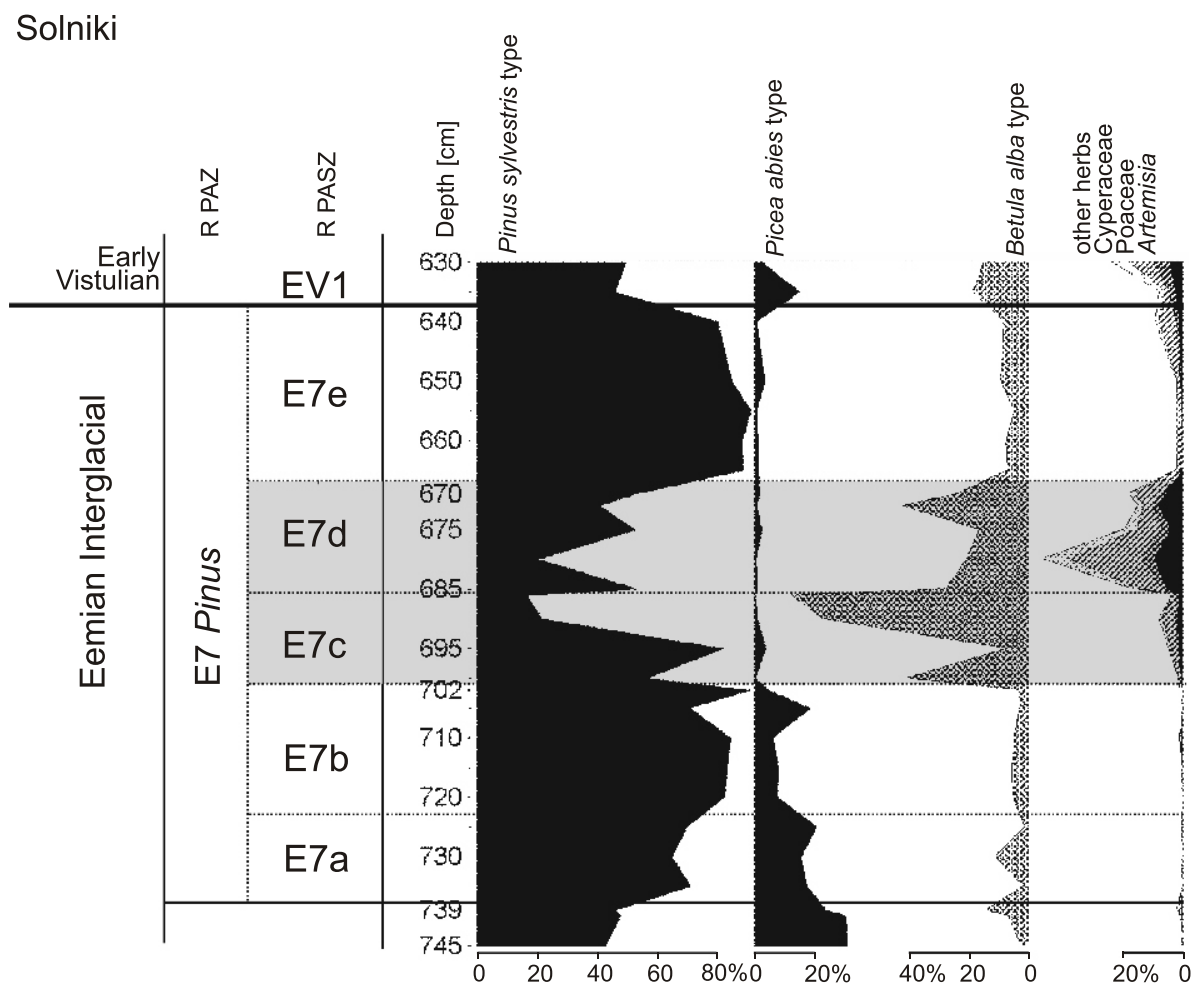

Fig. 2. Simplified pollen diagram from the Solniki profile illustrating changes of vegetation during the E7 Pinus regional pollen zone of the Eemian interglacial (according to Kupryjanowicz, 2008 - modified)

R PAZ - regional pollen assemblage zones, R PASZ - regional pollen assemblage subzones

(for characteristics see Table 1), grey rectangle indicates subzones representing the intra-Eemian cooling

Regional palynostratigraphy of the youngest, pine phase of the Eemian interglacial (E7 R PAZ) and the oldest part of the Early Vistulian (EV1 R PAZ) in Poland and pollen horizons representative of these units; regional pollen assemblage zones (R PAZ) according to Mamakowa (1989)

\begin{tabular}{|c|c|c|c|c|c|}
\hline \multicolumn{2}{|c|}{$\begin{array}{c}\text { R PAZ } \\
\text { Symbol and name }\end{array}$} & \multicolumn{2}{|c|}{$\begin{array}{c}\text { R PASZ } \\
\text { Symbol and name }\end{array}$} & \multirow{2}{*}{$\begin{array}{l}\text { Description of regional pollen zones or } \\
\text { subzones }\end{array}$} & \multirow[t]{2}{*}{$\begin{array}{l}\text { Description of pollen } \\
\text { horizon used for } \\
\text { drawing of maps } \\
\end{array}$} \\
\hline EV1 & $\begin{array}{l}\text { Poaceae-Artemi- } \\
\text { sia-Betula nana }\end{array}$ & & & & \\
\hline \multirow{5}{*}{ E7 } & \multirow{5}{*}{ Pinus } & E7e & Pinus-Betula & $\begin{array}{c}\text { Culmination of Pinus sylvestris t.; decline of } \\
\text { NAP and Betula alba t. }\end{array}$ & Peak of Pinus \\
\hline & & E7d & NAP & $\begin{array}{c}\text { Culmination of NAP values; still high propor- } \\
\text { tion of Betula alba t.; relatively low frequency } \\
\text { of Pinus sylvestris t. }\end{array}$ & Peak of NAP \\
\hline & & E7c & Betula & $\begin{array}{l}\text { Culmination of Betula alba t. pollen; rise in } \\
\text { NAP values; depression of Pinus sylvestris t.; } \\
\text { final disappearance of thermophilous trees } \\
\text { and shrubs. }\end{array}$ & Peak of Betula \\
\hline & & $\mathrm{E} 7 \mathrm{~b}$ & Pinus & $\begin{array}{c}\text { Maximum of Pinus sylvestris t. pollen; de- } \\
\text { crease of Picea abies t. and thermophilous } \\
\text { trees and shrubs. }\end{array}$ & Pinus maximum \\
\hline & & E7a & Pinus-Picea & $\begin{array}{c}\text { Systematic rise in Pinus sylvestris t. pollen; } \\
\text { relatively high, but gradually decreasing pro- } \\
\text { portion of Picea abies t., regular occurrence } \\
\text { of Carpinus betulus and Alnus pollen, but } \\
\text { with low values. }\end{array}$ & Middle pollen spectrum \\
\hline
\end{tabular}




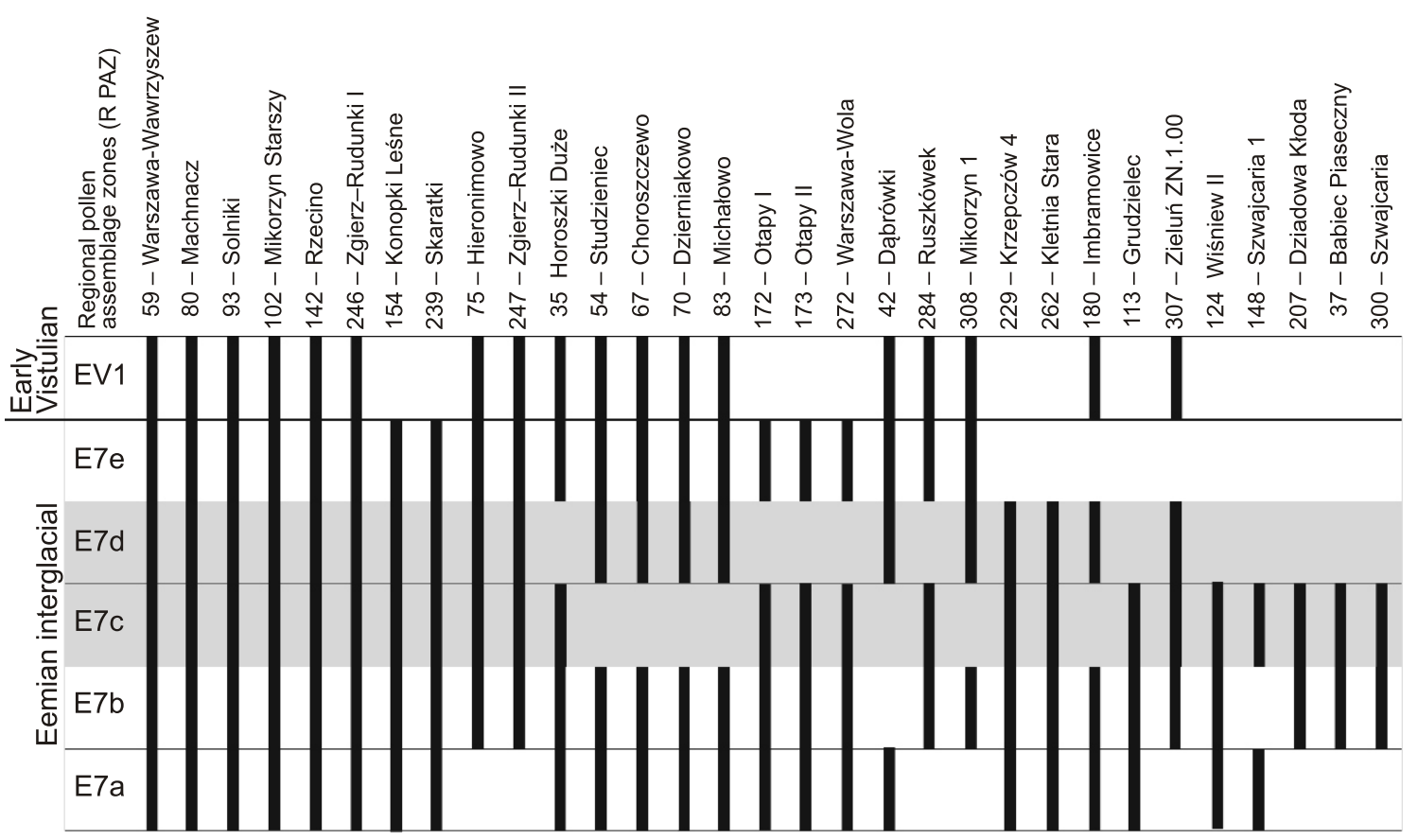

Fig. 3. Regional pollen assemblage subzones of the pine (E7) zone of the Eemian Interglacial and the first pollen zone (EV1) of the Early Vistulian (Weichselian) represented in particular studied profiles (the numbers of sites according to the Eemian isopollen data base; for locations of sites see Fig. 1)

Grey shading indicates subzones representing the intra-Eemian cooling

which were created by digitizing diagrams available in the literature or in other archives. These tables contain the data only for selected pollen spectra.

The pollen horizons for which isopollen maps were constructed are identified with only individual pollen spectra, selected within particular pollen zones or subzones (Table 1). Hence, these Eemian pollen horizons are not equivalents to the pollen assemblage zones (PAZ), or pollen assemblage subzones (PASZ) as defined by Birks (1986).

The nomenclature of pollen taxa was standardized for the tables submitted to the database. The calculation of percentages is based on the pollen sum of trees, shrubs, dwarf shrubs and terrestrial herbs. The set of isoline values for trees and shrubs consists of 19 percentage ranges $(0.01,0.1,0.5,1,2,3$, $5,7,10,15,20,25,30,35,40,50,60,70$ and $80 \%)$, and for herbaceous taxa 14 ranges $(0.01,0.1,0.2,0.5,0.7,1,2,3,5,7,10$, 20,30 and $40 \%$ ).

Palynological data were used to construct isopollen maps of the Eemian Interglacial for 18 different rank taxa of trees and shrubs, for 6 taxa of dwarf shrubs and herbs, and for the sum of non-arborescent plants (NAP, herbs). This paper presents maps for several selected taxa which best illustrate changes in vegetation associated with the late Eemian climatic oscillations. A complete series of maps for the entire Eemian Interglacial, and a detailed description of the method used, can be found in a monograph by Kupryjanowicz et al. (in print).

\section{RESULTS}

\section{E7A SUBZONE}

The pine zone (E7 R PAZ) represents the latest stage of the Eemian succession of vegetation. Progressive humidity and cooling of the climate, characteristic of the telocratic stage of the interglacial cycle, resulted in a change of habitat conditions and imposed a transformation of plant communities from the very beginning of this zone. Pine was the main forest-forming tree at that time across Poland. This is reflected in the isopollen maps by very high pine pollen values, which in most areas reach $60-70 \%$, and only in the south-west are slightly lower, 50-60\% (Fig. 4). Pine forest was perhaps like the modern Leucobryo-Pinetum (Granoszewski, 2003). This is a tall pine forest within the range of oceanic climate in central and eastern Central Europe (Matuszkiewicz, 2006), in which birch and spruce locally constitute an admixture. An isopollen map shows that the share of birch was greater in central, southern and eastern Poland (generally $5-7 \%$, locally to $10 \%$ ), while in the west and north its importance at this time was relatively smaller (3-5\%). The pollen values of Picea, ranging from $10-15 \%$ in the whole of Poland, and in the north-east even to15-20\% suggest that it was fairly abundant, and that it played a significant role in the communities of the whole area under consideration. Spruce may have occurred mainly in the already degrading wet alderwoods, and in riverine forests. Also its role in the expanding pine forests may have been prominent, especially in bog pinewoods. In the lowest areas perhaps even spruce-pine boreal forests occurred, especially in northeastern Poland.

Due to the spread of pine forests, in which there is little shade, the significance of open communities increased further. This is illustrated on isopollen maps by a high proportion of herbs (to $7-10 \%$ in southwestern and northeastern Poland). The greatest diversity of herbaceous plant taxa was associated with moist and boggy habitats, which dominated at that time in the landscape of many regions of Poland (e.g., Mamakowa, 1989; Granoszewski, 2003; Krupiński, 2005; Kupryjanowicz, 2008). The increasing role of these habitats is shown by an increase in the pollen of Poaceae and Cyperaceae. The grasses were possibly associated mainly with the boggy form of pine forest at that time (e.g., Granoszewski, 2003). Drier light forest 


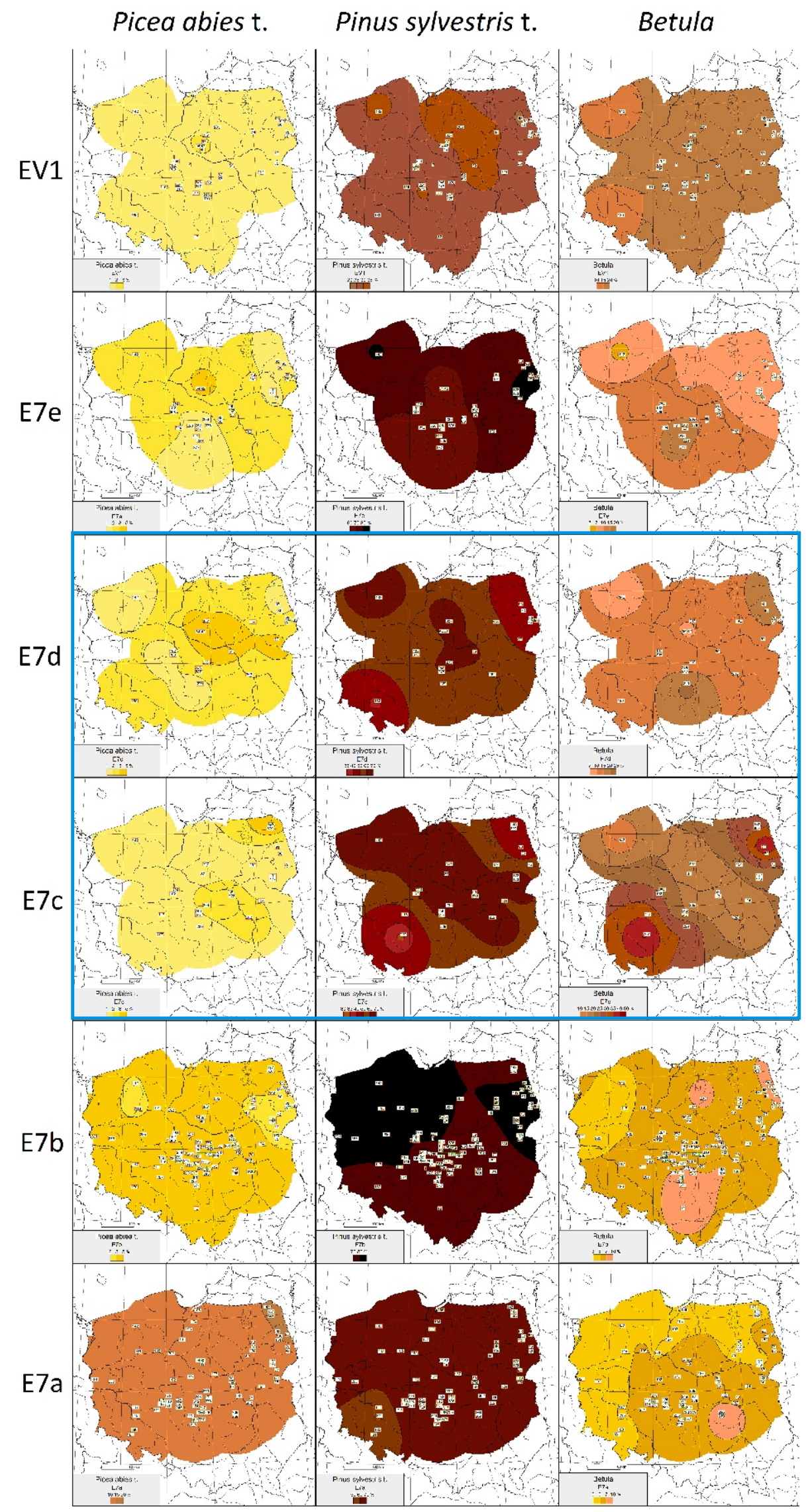

Fig. 4. Isopollen maps of selected pollen taxa illustrating the main vegetation changes beginning of the last glaciations 


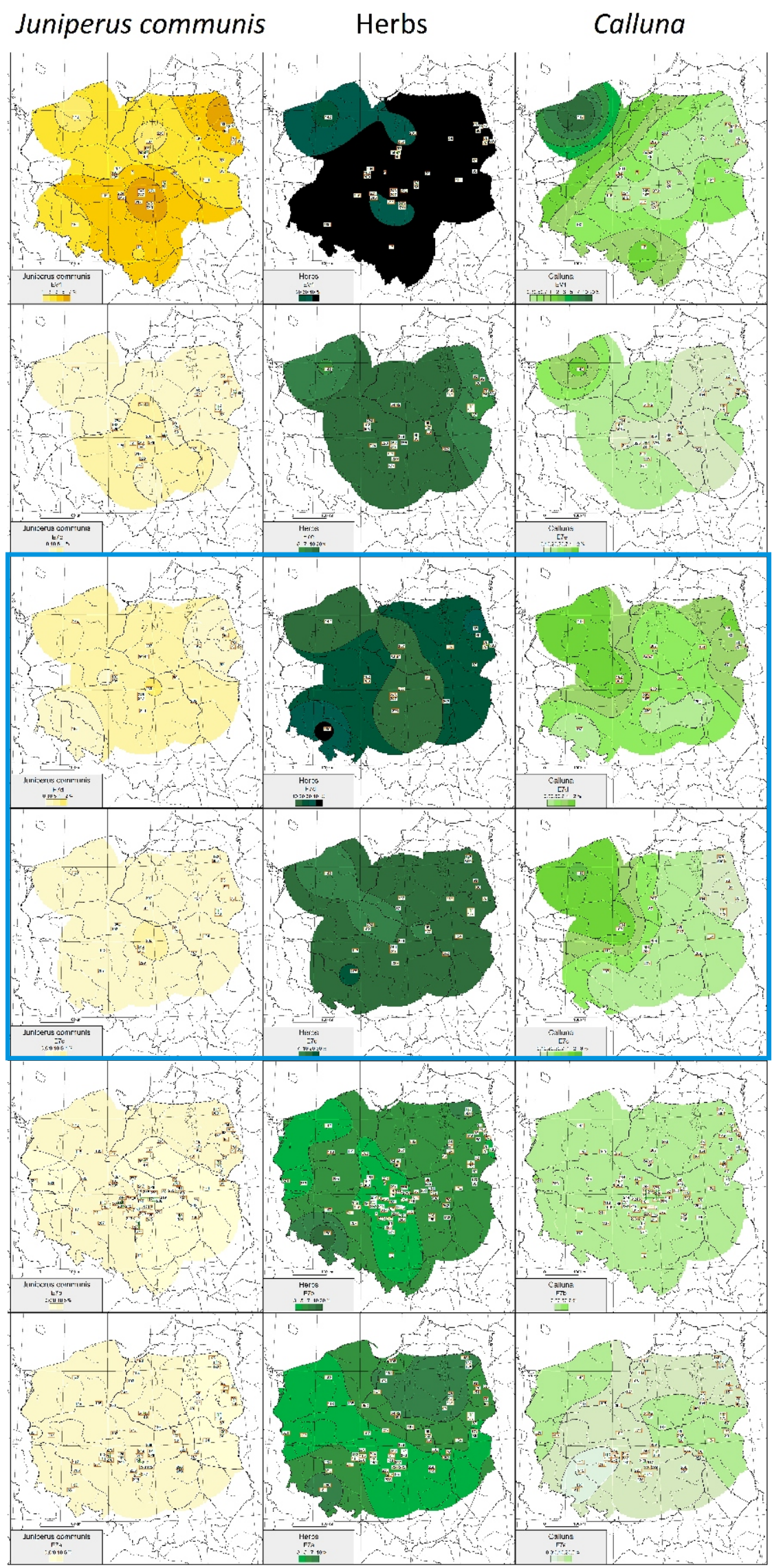

during the final phase of the Eemian Interglacial (E7 Pinus R PAZ) and at the very (EV1 Poaceae-Artemisia-Betula nana R PAZ) in Poland

for better quality of this figure see Appendix 1 in the online version, at doi: 10.7306/gq.1271 
habitats were perhaps occupied mainly by patches of heath, as is indicated by the increase in the pollen values of Calluna vulgaris, especially in northwestern, eastern and eastern central Poland.

In view of the changes taking place in the plant composition, the constant occurrence at that time of Hedera helix pollen, and the presence of Viscum album and Ilex aquifolium pollen is a problem that is hard to interpret (e.g., Mamakowa, 1989). These pollen grains are most probably connected with redeposition. However, Hedera and Viscum may have persisted in ecologically favourable habitats.

\section{E7B SUBZONE}

Pine reached its maximal interglacial spread in this subzone. In the whole of Poland, its pollen values increased above $70 \%$, and in the north-west and north-east even to $90 \%$. It formed thick, almost pure forests, probably developed as different communities. They occupied nearly all habitats. Apart from pine, which was the main forest tree, birch trees also grew there. Their role in northern and southwestern Poland was slightly greater than in the previous subzone, as suggested by an increased percentage share of Betula in these regions (generally to $7 \%$, and locally even to $10 \%$ ), as shown in the isopollen map; only in the north-west it was still under $5 \%$.

The expansion of pine and spread of birch were related to the decline of spruce and of all other forest trees. However, the relatively high values of Picea abies t. pollen (generally $3-5 \%$; $2-3 \%$ only locally in northeastern and northwestern Poland) indicate that spruce still played a substantial role in forest communities, and probably accompanied pine, forming pine-spruce forests. In sparse, well-lit coniferous forests the significance of open communities consequently increased. This is indicated by a further rise in the percentage amount of herbs, which for most Polish territory reach up to $7 \%$. Drier forest habitats were still occupied by heath, as indicated by the increase in the pollen frequency of Calluna vulgaris to $0.7 \%$ in the whole of Poland.

\section{E7C AND E7D SUBZONES - INTRA-INTERGLACIAL COOLING}

The E7c and E7d subzones of the pine zone represent a cold climatic oscillation. The record of that oscillation is included in many profiles studied from different regions of Poland. The cooling record is the best developed in the profile from Solniki in northern Podlasie (Kupryjanowicz, 2008). At this site, thanks to the high resolution of the pollen analysis, the two-step course of that oscillation was recognized for the first time (Fig. 2). The isopollen maps showed that a similar pattern of this oscillation is also recorded in several other profiles (Fig. 4). However, zones representing this intra-Eemian cooling are usually contained within a thin interval, and they may easily be omitted in studies based on random samples. This explains their presence only at some sites, which strongly hinders the reconstruction of the regional differences in vegetation changes.

This probably brief cold period was marked by the decline of pine and a strong increase in the proportion of birch. It is documented on the isopollen maps of the E7c subzone by a fall in Pinus pollen values generally $<70 \%$, in the north-east $<50 \%$, and in the south-west even $<35 \%$, as well as by a rise in Betula pollen proportion to generally $20 \%$, and in the north-east and south-west to $50 \%$. The area of the pine forests was substantially reduced. They were temporary replaced by birch forests. According to Granoszewski (2003), at that time birch may have locally formed stands of the Betuletum pubescentis type, in boggy former habitats of alder carr communities, acidified by spruce. Pine and spruce also grew there. Despite the temporary increase in the significance of birch, it seems that pine-spruce forests were still present. However, the role of spruce diminished significantly across the whole of Poland, which is reflected in decreased percentages of its pollen to $1-2 \%$, indicated in isopollen maps. Only in northeastern and central Poland the role of spruce was slightly more important $(3-5 \%$ and $2-3 \%$, respectively).

These changes were additionally accompanied by an increase in the proportion of herbs (usually to $20 \%$ ), including mainly Cyperaceae, Poaceae, Artemisia and numerous others (Mamakowa, 1989; Granoszewski, 2003; Krupiński, 2005; Kupryjanowicz, 2008). As a result of climate worsening and the degradation of soils, the forest probably retreated from the habitats where edaphic and hydrological conditions were less favourable. These habitats were occupied by communities of herbaceous plants, probably both on drier soils and on wetter ones. In northwestern Poland heathlands dominated by Calluna vulgaris (increase in pollen values to $3 \%$ ) and other members of the Ericaceae family (rise also to $3 \%$ - Winter et al., 2008) were developed at that time. In central Poland Juniperus appeared in greater amounts $(0.5-1 \%)$.

The E7d subzone represents the second stage of a cold climatic oscillation within the pine phase. The pollen record suggests a further cooling of the climate. It led to the reduction of birch forests, which were formed in the previous subzone (decline of Betula pollen values to $10 \%$, and locally in the north-west even to $7 \%$ ), and to the spread of the open communities (increase in the proportion of herbs to $30 \%$, in the north-east to $40 \%$, and in the south-west to $50 \%$ ). Moist habitats were mainly occupied by shrub tundra with shrub willow (e.g., Kupryjanowicz, 2008). In drier habitats, open steppe grass communities spread, with high proportions of Artemisia and Chenopodiaceae (e.g., Granoszewski, 2003). A decrease in forest cover may also be suggested by the increase of the role of Juniperus, which had already appeared in the previous subzone, and in this zone its pollen reached values of $1 \%$ across almost all of Poland, except the south-west and north-east. Juniperus spread across northwestern and northeastern Poland (its pollen values reach $2 \%$ in these regions).

It seems highly likely that the E7c and E7d subzones reflect some sudden climate change towards both cooling and wetness. The occurrence of a short-lived cold oscillation is also indicated by evidence of surface runoff in the deposits at several sites (e.g., Machnacz - Kupryjanowicz, 1994; Dzierniakowo Kupryjanowicz, 2008) in the form of sand and gravel lenses.

\section{E7E SUBZONE}

After the cold period, the climate became slightly warmer. Pine returned to places occupied for a time by birch and open vegetation - this is illustrated in the isopollen maps by a rise in Pinus sylvestris t. pollen across Poland (usually to $80 \%$, and in the east and north-west to 90\%) and by a fall in Betula (most marked in northern and eastern parts of the country, $<10 \%$; in other regions to $10-20 \%$ ), herbs (generally to $10-20 \%$, and in the east and north-west to $7-10 \%$ ) and Calluna (generally $<0.2 \%$; only in the north-west pollen values remained similar to those in the previous period, $1-2 \%$ ). Pine forests spread anew, but in a structure different to that of the E7a and E7b subzones. They were sparser, with a clearly lower proportion of spruce, without fir and thermophilous deciduous trees, which were replaced by birch. The area of open communities was significantly smaller than in the previous subzone. 
Changes during the E7e subzone can be explained by a temporary amelioration in the climate at the very end of the Eemian Interglacial (Kupryjanowicz, 2008). However, the general tendency of the vegetation succession during the $E 7 d$ subzone would point to continuous deterioration of the climate starting directly after the short warming at the beginning of this subzone. In the Horoszki profile this is supported by a decrease in organic matter, a decreasing trend in the concentration of sporomorphs, and by an accompanying increase in the proportion of herbs (Granoszewski, 2003).

The low amounts of thermophilous tree pollen probably reflect long-distance transport. The pine forest was boreal in nature, and in the youngest part of the E7e subzone even had features of forest tundra, perhaps similar to the modern communities of this type (Norin, 1961), and was clearly in retreat.

\section{EV1 ZONE}

An intensification in climate change towards cooling finally brought about the thinning and retreat of forest communities from areas of Poland and the spread of open plant communities. This process is reflected on the isopollen maps as a very marked increase in herbaceous plant pollen (above $40 \%$ in whole Poland, except in its northwestern part where the share of herbs was relatively low, $30-40 \%$, but the proportion of Calluna significantly increased, locally even to $20 \%$ ), and the rapid fall of pollen values of all trees (decline of Pinus sylvestris t. pollen values to $25-30 \%$, Betula to $15-20 \%$, and Picea abies t. $<2 \%$ across almost the whole country), which marks the boundary between the interglacial and glacial succession of vegetation, i.e. between the telocratic and cryocratic stages of the glacial/interglacial cycle.

These changes are accompanied by a successive increase in the proportion of coarser sand fractions in the deposits at numerous sites, symptomatic of the re-intensification of erosional processes (e.g., Mamakowa, 1989; Krupiński, 2005; Kupryjanowicz, 2008). The rise in the pollen values of Alnus, Corylus, Tilia, Quercus, and Ulmus indicates redeposition of interglacial sediments in the layer in which the proportion of coarser sand fractions of the sediments reaches a maximum.

This zone represents the first post-Eemian cold period of stadial character. The vegetational landscape at that time was tundra with clusters of willows and probably shrub birches. A further increase in the herbaceous plant pollen value, up to $50 \%$, provides evidence of the continuously progressing expansion of various open communities. The distinct increase in the pollen values of Artemisia and Poaceae suggests the rising importance of grass communities, perhaps steppe-like in nature.

Shrub communities, the appearance of which is emphasised by the occurrence of pollen of Juniperus, gained in significance. Among the tree species, only pine and birch might have occurred, forming small patches in open areas.

\section{DISCUSSION}

The record of an intra-Eemian cold oscillation in the final, pine phase of the last interglacial (E7 R PAZ) is noted in 31 profiles from Poland. In all these profiles the sections belonging to the Pinus zone are made up of homogeneous undisturbed lacustrine deposits (e.g., Mamakowa, 1989; Kupryjanowicz, 1994 2008; Kupryjanowicz and Drzymulska, 2002; Granoszewski, 2003; Krupiński, 2005). Therefore, the cold oscillation described cannot result from sedimentary reworking. The record of the cooling is the best developed in the profile from the
Solniki site in northeastern Poland. In the Solniki pollen profile, thanks to the high resolution of pollen analysis, a two-step course of this cooling is visible (Kupryjanowicz, 2008). The results of Cladocera, magnetic susceptibility and stable isotope analyses from these same profiles support this course of climate change in the region (Kupryjanowicz et al., 2005; Mirosław-Grabowska et al., 2015). Similar additional analyses were carried also at several other sites examined palynologically, and everywhere they were consistent with a temporary drop in temperature within the pine phase of the Eemian Interglacial (e.g., Rzecino - Niska and Mirosław-Grabowska, 2015; Studzieniec - Mirosław-Grabowska and Niska, 2007).

The retreat of pine during the $E 7 c$ and $E 7 d$ subzones is signalled on the isopollen maps by a significant fall in Pinus pollen values at all sites studied. At the same time there is a rise in the amount of Betula pollen, as can be clearly seen on the isopollen maps of this taxon. Such a change may reflect a cooling of the climate or an increase in its humidity. Similar oscillations, expressed in the palynological record by a decrease of percentage values of Pinus pollen and an increase in the Betula pollen proportion, took place also in the early Holocene during the Preboreal period when pine forest dominated, and are relatively well documented (e.g., Allen et al., 2002; Feurdean et al., 2008; Pèlachs et al., 2011; Wanner et al., 2011).

Subzone E7b represents a period of the maximal interglacial spread of pine forests. Spruce gradually lost its position in forests. Thermophilous trees were almost completely absent. All these facts suggest relatively cold climatic conditions with a continental character. However, the mean July temperature was not lower than $+12^{\circ} \mathrm{C}$ (Granoszewski, 2003; Kupryjanowicz, 2008). The mean January temperature decreased below $-5^{\circ} \mathrm{C}$. A multi-method approach by Brewer at al. (2008) also showed a decrease in temperatures and an increase in dry conditions after 120 ka BP. In subzone E7c, the established Pinus forest was invaded by Betula. A cooling of the climate seems to be the most probable reason for this change. The mean July temperature probably decreased to about $+12^{\circ} \mathrm{C}$ at that time (Kupryjanowicz, 2008). In subzone E7d, the significant reduction in areas of boreal pine-birch forests, and the spread of herbaceous communities dominated by Artemisia, took place. These changes point to a relatively dry continental climate, with the mean January temperature $<-10^{\circ} \mathrm{C}$, and the mean July temperature only slightly higher than $+10^{\circ} \mathrm{C}$ (Kupryjanowicz, 2008). In subzone E7e, the new expansion of pine forest and a decline of birch and herbs undoubtedly reflect a slightly more temperate climate. The mean July temperature once again had to be $>+12^{\circ} \mathrm{C}$, and the mean January temperature $>-5^{\circ} \mathrm{C}$ (Granoszewski, 2003; Kupryjanowicz, 2008).

Beaulieu and Reille (1989) have already described a similar cold oscillation in the late part of the Eemian Interglacial in Les Echets, southern France. The authors correlate it with similar oscillations recorded in some pollen profiles from Germany (Odderade - Averdieck, 1967; Sulzberg-Baden - Welten, 1981; Gondiswill - Wegmüller, 1986), France (La Grande Pile Woillard, 1978) and The Netherlands (Brørup - Andersen, 1961). This oscillation is also distinctly visible in the reconstruction of mean January and July temperatures in Bispingen, northern Germany (Kühl and Litt, 2003).

The fact that the cold oscillation in the Eemian pine zone is not recorded in numerous profiles from almost the whole of Europe may result from different reasons. In cases when the thickness of sediments, in which the final part of the Eemian Interglacial is recorded, is low, the oscillation may not be noticed with the standard distance between analysed pollen samples (every $5-10 \mathrm{~cm}$ ). According to Beaulieu and Reille (1989), it is also possible that this short and low-amplitude oscillation in- 
duced notable vegetation changes only near ecotones in the northern central and eastern Europe.

A correlation of intra-Eemian climatic oscillations contained in the terrestrial records from European (including Polish) sites with a cold event observed in Greenland ice cores or deep marine cores is very difficult. In the great majority of cases, the lack of absolute age determinations of those changes is the first, and undoubtedly the most important reason for the difficulties. In profiles that were not subjected to pollen analysis and absolute dating, there is no certainty that they contain a record of the whole interglacial. In consequence of that, there is an inability to define in which part of the interglacial the recorded change took place.

At the end of the last interglacial, the pollen and geochemical data for a few sequences in Central and Eastern Europe show a gradual cooling during the interglacial/glacial transition. This can be correlated with the continuous temperature fall at ca. 120 ka BP in the NGRIP ice core from central Greenland (North Greenland Ice Core Project, 2004). Within this global climatic transition are clear indications of instabilities of climate and vegetation dynamics, possibly caused through brief cooling and then warming towards the very end of the last interglacial in Central European profiles. Moreover, Menke and Tynni (1984) referred to environmental oscillations in profiles from northwestern Germany. Strong climate fluctuations accompanied by intensive loess deposition during the Late Eemian aridity pulse, and an abrupt cooling event exactly at the time of the Last Glacial inception at ca. $118 \mathrm{ka} \mathrm{BP}$, were also noted by Sirocko et al. (2005), and Seelos and Sirocko (2007) in northern and western Germany. Possibly, these results correspond to the sea level rise inferred worldwide in the final stage of the last interglacial (Hearty et al., 2007). In Eastern Europe, slight warming oscillations occurred during the very end of the last interglacial in the profile from Ples (Upper Volga region), and these also were earlier noted in several other profiles in the north-west of the Russian Plain and Lithuania (e.g., Grichuk, 1961; Kondratene, 1996; Novenko et al., 2008b).

The correlation of the climatic fluctuation detected between the continental limnic sequences in Poland and also in the whole of Central and Eastern Europe is well-established - it definitely occurred during E7 R PAZ, i.e. before the beginning of the first Early Last Glacial stadial (Herning). Probably, the climate before the interglacial/glacial transition was characterized by internal instability, resulting in the sequence of climatic oscillations observed, within the overall trend towards cooling. The precise correlation between the profiles investigated and the patterns observed in the NGRIP ice core remains under discussion. There are some problems with the correlation of DO 25 in NGRIP with terrestrial records. Johnsen et al. (2005) reported that the warming event DO 25 lasted some $4 \mathrm{ka}$. Such a period seems to be too long for correlation with the warming event at the very end of the last interglacial in terrestrial records, although the exact duration of the observed warming events in lake profiles presented here remains unclear.
For the Eemian Interglacial, as for the Holocene, after significant warming during the transition from the glacial to interglacial and reaching the climatic optimum, stable warm climatic conditions set in with a gradual temperature decrease with time. It appears that in Central Europe a short cooling and warming phase at the very end of the last interglacial preceded the final transition to glacial conditions. This is part of the observed increase in climatic and environmental instability during this global warm/cold transition, which appears to be at least a European phenomenon. The observed climatic and environmental instability during the final part of the last interglacial could be seriously considered as a possible general natural characteristic of global warm/cold transition periods. Therefore, detailed studies of these phenomena are important for evaluating and understanding the currently observed and very controversially discussed (e.g., Velichko et al., 2005; Keenlyside et al., 2008) climatic trends, and for detecting anthropogenic input in climate change.

\section{SUMMARY AND CONCLUSIONS}

In 31 pollen profiles from different regions of Poland, clearly defined climatic fluctuations are recorded by pollen data at the end of the Eemian Interglacial. They contain a strong cooling in the middle part of the pine phase of the interglacial (subzones E7c and E7d of the E7 Pinus regional pollen zone), and subsequent warming at the very end of this phase (E7e subzone). The pan-regional character of the Late Eemian cold event is clearly noticeable on isopollen maps as a significant reduction in Pinus pollen throughout the whole Polish territory. The drop in temperature was at first accompanied by an increased proportion of Betula pollen (E7c subzone), and then also an increase in the proportion of pollen of non-arboreal plants (E7d subzone). The warming at the very end of the Eemian Interglacial (E7e subzone) is illustrated on isopollen maps by the re-increase of Pinus pollen in the whole territory of Poland and by a decline of Betula and herbaceous pollen. This fluctuation of climate was not just a local or regional phenomenon, but seems to have been an event on the scale of the whole of Western, Central and Eastern Europe.

Acknowledgements. We thank $\mathrm{Ch}$. Turner and anonymous reviewer for helpful comments on earlier drafts. The investigations have been supported by the Polish Ministry of Science and Higher Education (project no. N N304 352238) and by the statutory funds of the University of Białystok, Polish Geological Institute - National Research Institute, W. Szafer Institute of Botany PAS, Maria Skłodowska-Curie University, AGH University of Science and Technology, Adam Mickiewicz University, University of Warsaw, University of Wrocław, and University of Silesia.

\section{REFERENCES}

Allen, J.R.M., Watts, W.A., McGee, E., Huntley, B., 2002. Holocene environmental variability the record from Lago Grande di Monticchio, Italy. Quaternary International, 88: 69-80.

Andersen, S.Th., 1961. Vegetation and its environment in Denmark in the Early Weichselian Glacial (Last Glacial). Danmarks Geologiske Undersogelse, 75: 1-175.
Anklin, M., Barnola, J.M., Beer, J., Blunier, T., Chappellaz, J., Clausen, H.B., Dahl-Jensen, D., Dansgaard, W., de Angelis M., Delmas R.J., 1993. Climate instability during the last interglacial period recorded in the GRIP ice core. Nature, 364: 203-207. 
Averdieck, F.R., 1967. Die Vegetationsentwicklung des EemInterglazials und der Fruh Wurm-Interstadiale von Odderade/ Schleswig-Holstein. Fundaments (B), 2: 101-125

Beaulieu, de, J.-L., Reille, M., 1989. The transition from temperate phase to stadials in the long upper Pleistocene sequence from les Echets (France). Palaeogeography, Palaeoclimatology, Palaeoecology, 72: 147-159.

Beaulieu, de, J.-L., Reille, M., 1992a. Long Pleistocene pollen sequences from the Velay Plateau (Massif Central, France). Vegetation History and Archaeobotany, 1: 233-242.

Beaulieu, de, J.-L., Reille, M., 1992b. The last climatic cycle at La Grande Pile (Vosges, France). Quaternary Science Reviews, 11: 431-438.

Ber, A., Krupiński, K. M., Zabielski, R., 1998. Profil osadów interglacjalu eemskiego i zlodowacenia Wisły w Szwajcarii k. Suwałk w świetle nowych danych (in Polish). In: Stratygrafia plejstocenu Polski. Nowe jednostki stratygraficzne Pojezierza Mazurskiego (eds. L. Marks, S. Lisicki, J. Medek and K Pochocka): 26-27. Państwowy Instytut Geologiczny, Warszawa.

Bernabo, J.C., Webb, T., 1977. Changing patterns in the Holocene pollen record of Norheastern Norh America: A mapped summary. Quaternary Research, 8: 64-96.

Bertsch, K., 1953. Geschichte des deutschen Waldes. Gustaw Fischer Verlag, Jena.

Birks, H.J.B., 1986. Numerical zonation, comparison and correlation of Quaternary pollen-stratigraphical data. In: Handbook of Holocene Palaeoecology and Palaeohydrology (eds. B.E. Berglund and M. Ralska-Jasiewiczowa): 743-774. J. Wiley \& Sons Ltd., Chichester-Toronto.

Birks, H.J.B., Saarnisto, M.V., 1975. Isopollen maps and principal component analysis of Finnish pollen data for 4000, 6000, and 8000 years ago. Boreas, 4: 77-96.

Bitner, K., 1956. Interglacial flora in Otapy/District Białystok (in Polish with English summary). Biuletyn Instytutu Geologicznego, 100: $61-142$

Boettger, T., Novenko, E.Yu., Velichko, A.A., Borisova, O.K. Kremenetski, K.V., Knetsch, S., Junge, F.W., 2009. Instability of climate and vegetation dynamics in Central and Eastern Europe during the final stage of the Last Interglacial (Eemian, Mikulino) and Early Glaciation. Quaternary International, 207 137-144.

Borisova, O.K., Novenko, E.Yu., Velichko, A.A., Kremenetski, K.V., Junge, F.W., Boettger, T., 2007. Vegetation and climate changes during the Eemian and Early Weichselian in the Upper Volga region (Russia). Quaternary Science Reviews, 26: 2574-2585.

Borówko-Dłużakowa, Z., 1960. Two new interglacial stratigraphical columns from Warsaw in the light of palaeobotanical investigations (in Polish with English summary). Biuletyn Instytutu Geologicznego, 150: 105-130.

Borówko-Dłużakowa, Z., Halicki, B., 1957. Interglacial sections of the Suwałki region and of the adjacent territory (in Polish with English summary). Acta Geologica Polonia, 7: 361-401.

Brewer, S., Guiot, J., Sánchez-Gońi, M.F., Klotz, S. 2008. The climate in Europe during the Eemian: a multi-method approach using pollen data. Quaternary Science Review, 27: 2303-2315.

Cheddadi, R., Mamakova, K., Guiot, J., de Beaulieu, J.-L., Reille, M., Andrieu, V., Granoszewski, W., Peyron, O., 1998. Was the climate of the Eemian stable? A quantitative climate reconstruction from seven European pollen records. Palaeogeography, Palaeoclimatology, Palaeoecology, 143: 73-85.

Chmielewski, W., 1961. Guide-book of excursion C. The Łódź region - Skaratki. VI Congr. INQUA, Warsaw: 71-75.

Dansgaard, W., Johnsen, S.J., Clausen, H.B., Dahi-Jansen, D. Gundestrup, N.S., Hammer, C.U., Huidberg, C.S., Steffensen, J.P., Sveinbjornsdottir, A.E., Jouzel, J., Bond, G., 1993. Evidence for general instability of past climate from a 250-kyr. Ice-core record. Nature, 364: 218-220.

Davis, M.B., 1976. Pleistocene biogeography of temperate deciduous forests. Geoscience and Man, 13: 133-26.
Davis, R.B., Webb, T. III, 1975. The contemporary distribution of pollen in eastern North America: a comparison with the vegetation. Quaternary Research, 5: 395-434

Donner, J.J., 1963. The zoning of the post-glacial pollen diagrams in Finland and the main changes in the forest composition. Acta Botanica Fennica, 65: 2-40.

Eissmann, L., 2002. Quaternary geology of eastern Germany (Saxony, Saxony Anhalt, South Brandenburg, Thuringia), type area of the Elsterian and Saalian Stages in Europe. Quaternary Science Reviews, 21: 1275-1346.

Feurdean, A., Klotz, S., Mosbrugger, V., Wohlfarth, B., 2008. Pollen-based quantitative reconstructions of Holocene climate variability in NW Romania. Palaeogeography, Palaeoclimatology, Palaeoecology, 260: 494-504.

Field, M.H., Huntley, B., Muller, H., 1994. Eemian climate fluctuations observed in a European pollen record. Nature, 371: 779-783.

Firbas, F., 1949. Spät- und nacheiszeitliche Waldgeschichte Mitteleuropas nördlich der Alpen. Gustaw Fischer Verlag, Jena.

Fronval, T., Jansen, E., 1996. Rapid changes in ocean circulation and heat flux in the Nordic seas during the last interglacial period. Nature, 383: 806-810.

Granoszewski, W., 2003. Late Pleistocene vegetation history and climatic changes at Horoszki Duże, eastern Poland: a palaeobotanical study. Acta Palaeobotanica, Suppl., 4: 3-95.

Grichuk, V.P., 1961. Fossil floras as a paleontological basis of Quaternary stratigraphy (in Russian). In: Relief and Stratigraphy of Quaternary Deposits on the North-west of Russian Plain (ed. K.K. Markov): 25-71. USSR Academy of Sciences Press, Moscow.

GRIP, 1993. Climatic instability during the last interglacial period revealed in the Greenland summit ice-core. Nature, 364: 203-207.

Grootes, P. M., Stuiver, M., White, J.W.C., Johnsen, S.J., Jouzel, J., 1993. Comparison of the oxygen isotope records from the GISP2 and GRIP Greenland ice cores. Nature, 366: 552-554.

Guiot, J., de Beaulieu, J. L., Cheddadi, R., David, F., Ponel, P., Reille, M., 1993. The climate in Western Europe during the last Glacial/Interglacial cycle derived from pollen and insect remains. Palaeogeography, Palaeoclimatology, Palaeoecology, 103: 73-93.

Guiter, F., Andrieu-Ponel, V., de Beaulieu, J.L., Cheddadi, R., Calvez, M., Ponel, P., Reille, M., Keller, T., Goeury, C., 2003. The last climatic cycles in western Europe: a comparison between long continuous lacustrine sequences from France and other terrestrial records. Quaternary International, 111: 59-74.

Hearty, P.J., Hollin, J.T., Neuman, A.C., O'Leary, M.J., McCulloch, M., 2007. Global sea level fluctuations during the Last Interglaciation (MIS 5e). Quaternary Science Reviews, 26: 2090-2112.

Huntley, B., Birks, H.J.B., 1983. An Atlas of Past and Present Pollen Maps for Europe: 0-13000 years ago. Cambridge University Press, Cambridge.

Janczyk-Kopikowa, Z., 1986. Orzeczenie dotyczące próbek z miejscowości Kletnia Stara, ark. Dęblin (in Polish). Central Geological Archives, Polish Geological Institute, Warsaw.

Janczyk-Kopikowa, Z., 1987. Orzeczenie dotyczące próbek z wiercenia Kletnia Stara, ark. Dęblin (in Polish). Central Geological Archives, Polish Geological Institute, Warszawa.

Janczyk-Kopikowa, Z., 1997. Analiza pyłkowa osadów interglacjału eemskiego w Ruszkówku na Pojezierzu Kujawskim (in Polish). Przegląd Geologiczny, 45: 101-104.

Jastrzębska-Mamełka, M., 1985. The Eemian Interglacial and the Early Vistulian at Zgierz-Rudunki in the Łódź Plateau (in Polish with English summary). Acta Geographica Lodziensia, 53: $1-75$.

Johnsen, S.J., Steffensen, J.P., Dahl-Jensen, D., Landais, A., Chappellaz, J., 2005. In and out of a glacial. In: Book of Abstracts of DEKLIM/PAGES conference, Mainz, Germany: 41-42. 
Keenlyside, N.S., Latif, M., Jungclaus, J., Kornblueh, L., Roeckner, E., 2008. Advancing decadal-scale climate prediction in the North Atlantic sector. Nature, 453: 84-88.

Klatkowa, H., 1972. Paleogeografia Wyżyny Łódzkiej i obszarów sąsiednich podczas lodowacenia warciańskiego (in Polish). Acta Geographica Lodziensia, 28.

Klotz, S., Guiot, J., Mosbrugger, V., 2003. Continental European Eemian and early Wurmian climate evolution: Comparing signals using different quantitative reconstruction approaches based on pollen. Global and Planetary Change, 36: 277-294.

Klotz, S., Müller U.C., Mosbrugger, V., Beaulieu, de, J.-L., Reille, M., 2004. Eemian to early Würmian climate dynamics: History and pattern of changes in central Europe. Palaeogeography, Palaeoclimatology, Palaeoecology, 211: 107-126.

Kondratene, O., 1996. Stratigraphy and Paleogeography of Quaternary in Lithuania. Academia-Press, Vilnius.

Kotarbiński, J., Krupiński, K.M., 1995. Eemian Interglacial deposits in Studzieniec and Babiec Piaseczny near Sierpc (central Poland) (in Polish with English summary). Przegląd Geologiczny, 43: 565-571.

Krupiński, K.M., 1995. Orzeczenie paleobotaniczne dotyczące próbek osadów organicznych z otworu wiertniczego Studzieniec i Babiec Piaseczny, ark. Sierpc (in Polish). Central Geological Archives, Polish Geological Institute, Warszawa.

Krupiński, K.M., 1998. Sprawozdanie z badań „Opracowanie graficzne i interpretacja diagramu pyłkowego osadów interglacjalnych ze Szwajcarii" (in Polish). Central Geological Archives, Polish Geological Institute, Warszawa.

Krupiński, K.M., 2005. The investigations of the Younger Pleistocene lacustrine sediments of the Płock Upland (in Polish with English summary). Prace Państwowego Instytutu Geologicznego, 184: 3-58.

Krupiński, K.M., Morawski, W., 1993. Geological position and pollen analysis of Eemian interglacial sediments of Warsaw-Wawrzyszew. Acta Palaeobotanica, 33: 309-346.

Kühl, N., Litt, T., 2003. Quantitative time series reconstruction of Eemian temperature at three European sites using pollen data. Vegetation History and Archaeobotany, 12: 205-214.

Kühl, N., Litt, T., Schölzel, C., Hense, A., 2007. Eemian and Early Weichselian temperature and precipitation variability in northern Germany. Quaternary Science Reviews, 26: 3311-3317.

Kukla, G., McManus, J.F., Rousseau, D.D., Chuine, I., 1997. How long and how stable was the last interglacial? Quaternary Science Reviews, 16: 605-612.

Kukla, G., Bender, M.D., de Beaulieu, J.-L., Bond, G., Broecker, W.S., Cleveringa, P., Gavin, J.E., Herbert, T.D., Imbrie, J., Jouzel, J., Keigwin, L.D., Knudsen, K.-L., McManus, J., Merkt, J., Muhs, D.R., Müller, H., Poore, R.Z., Porter, S.C., Seret, G., Shackleton, N.J., Turner, C., Tzedakis, P.C., Winograd, I.J., 2002. Last interglacial climates. Quaternary Research, 58: 2-13.

Kupryjanowicz, M., 1991. Eemian, Early and Late Vistulian, and Holocene vegetation in the region of Machnacz peat-bog near Bialystok (NE Poland) - preliminary results. Acta Palaeobotanica, 31: 215-225.

Kupryjanowicz, M., 1994. Zmiany roślinności rejonu torfowisk Machnacz w Puszczy Knyszyńskiej w czasie interglacjału eemskiego, vistulianu i holocenu (in Polish). Ph.D. thesis, Archives of W. Szafer Institute of Botany, Polish Academy of Sciences, Kraków.

Kupryjanowicz, M., 2008. Vegetation and climate of the Eemian and Early Vistulian Lakeland in northern Podlasie. Acta Palaeobotanica, 48: 3-130.

Kupryjanowicz, M., Drzymulska, D., 2002. Eemian and Early Vistulian vegetation at Michałowo (NE Poland). Studia Quaternaria, 19: 19-25.

Kupryjanowicz, M., Ciszek, D., Mirosław-Grabowska, J., Marciniak, B., Niska, M., 2005. Two climatic oscillations during the Eemian Interglacial - preliminary results of the multiproxy researches of the palaeolake at Solniki, NE Poland. Polish Geological Institute Special Papers, 16: 1-142.
Kupryjanowicz, M., Nalepka, D., Madeyska, E., eds, (in print). Eemian history of vegetation in Poland based on isopollen maps. W. Szafer Institute of Botany, Polish Academy of Sciences, Kraków.

Kuszell, T., 1998. New interglacial sites in southwestern Poland (in Polish with English summary). Biuletyn Państwowego Instytutu Geologicznego, 385: 127-141.

Litt, Th., Junge, F.W., Boettger, T., 1996. Climate during the Eemian in north-central Europe - a critical review of the palaeobotanical and stable isotope data from central Germany. Vegetation History and Archaeobotany, 5: 247-256.

Malkiewicz, M., 2002. The history of vegetation of the Eemian Interglacial in the Great Polish Lowland. Acta Societatis Botanicorum Poloniae, 71: 311-321.

Mamakowa, K., 1989. Late Middle Polish Glaciation, Eemian and Early Vistulian vegetation at Imbramowice near Wrocław and the pollen stratigraphy of this part of the Pleistocene in Poland. Acta Palaeobotanica, 29: 11-176.

Mamakowa, K., 2003. Plejstocen (in Polish). In: Palinologia (eds. S. Dybova-Jachowicz and A. Sadowska): 235-266. Wydawnictwa Instytutu Botaniki PAN, Kraków.

Matuszkiewicz, W., 2006. Przewodnik do oznaczania zbiorowisk roślinnych w Polsce (in Polish). Wydawnictwo Naukowe PWN, Warszawa.

Menke, B., Tynni, R., 1984. Das Eeminterglazial und das Weichselfrühglazial von Rederstall/Dithmarschen und ihre Bedeutung für die mitteleuropäische Jungpleistozän-Gliederung. Geologisches Jahrbuch, A76: 3-120.

Mirosław-Grabowska, J., Niska, M., 2007. Reconstruction of environmental conditions of Eemian palaeolake at Studzieniec (Central Poland) on the basis of stable isotope and Cladocera analyses. Quaternary International, 162-163: 195-204.

Mirosław-Grabowska, J., Niska, M., Kupryjanowicz, M., 2015. Reaction of lake environment on the climatic cooling - Transition from the Eemian Interglacial to Early Vistulian on the basis of Solniki palaeolake sediments (NE Poland). Quaternary International, doi: 10.1016/j.quaint.2015.03.056

Moe, D., 1970. The Post-Glacial immigration of Picea abies into Fennoscandia. Botaniska Notiser, 123: 61-66.

Müller, H., 1974. Pollenanalytische Untersuchungen und Jahresschichtenzählung an der eemzeitlichen Kieselgur von Bispingen/Luhe. Geologisches Jahrbuch, A21: 149-169.

Nalepka, D., Walanus, A., 2003. Data processing in pollen analysis. Acta Palaeobotanica, 43: 125-134.

Niska, M., Mirosław-Grabowska, J., 2015. Eemian environmental changes recorded in lake deposits from Rzecino (NW Poland): Cladocera, isotopic and selected geochemical data. Journal of Paleolimnology, 53: 89-105.

Norin, B.N., 1961. What is forest-tundra? (in Russian) Botanicheskiy Zhurnal, 46: 21-38.

North Greenland Ice Core Project, 2004. High-resolution record of Northern Hemisphere climate extending into the last interglacial period. Nature, 431: 147-151.

Novenko, E.Yu., Seifert-Eulen, M., Boettger, T., Junge, F.W., 2008a. Eemian and Early Weichselian vegetation and climate history in Central Europe: a case study from the Klinge section (Lusatia). Review of Palaeobotany and Palynology, 151: 72-78.

Novenko, E.Yu., Zuganova, I.S., Koslov, D.N., 2008b. Vegetation covers development in Central Forest Reserve during Late Pleistocene (in Russian). Izvestiya Russian Academy of Sciences. Series of Geography, 1: 87-96.

Obidowicz, A., Madeyska, E., Turner Ch., eds., 2013. Postglacial history of vegetation in the Polish part of the Western Carpathians besed on isopollen maps. W. Szafer Institute of Botany, Polish Academy of Sciences, Kraków.

Pèlachs, A., Juliá, R., Pérez-Obiol, R., Soriano, J.M., Bal, M.C., Cunill, R., Catalan, J., 2011. Potential influence of Bond events on mid-Holocene climate and vegetation in southern Pyrenees as assessed from Burg lake LOI and pollen records. The Holocene, 21: 95-104. 
Pidek, I.A., Terpiłowski, S.,1993. Eemian and early Vistulian organogenic deposits at Wiśniew near Siedlce (in Polish). Annales UMCS, Sect. B, 48: 229-238.

Pidek, I.A., Terpiłowski, S., 1995a. Osady interglacjału eemskiego w obniżeniu wytopiskowym na plateau kemowym w Wiśniewie koło Siedlec (in Polish). In: II Konferencja "Stratygrafia plejstocenu Polski", Grabanów, 18-20 września 1995 r. (ed. L. Marks): 28. Instytut Geologii Podstawowej UW, Warszawa.

Pidek, I.A., Terpiłowski, S., 1995b. Emskie osady organogeniczne w Wiśniewie koło Siedlec (in Polish). In: Problemy geomorfologi i paleogeografii czwartorzędu: konferencja dedykowana Prof. dr Henrykowi Maruszczakowi, Lublin, 10-11 kwietnia 1995 r Materiały (ed. J. Wojtanowicz): 46-48. ZGFiP UMCS, Lublin.

POLPAL http://adamwalanus.pl/Polpal.html.

Ralska-Jasiewiczowa, M., 1983. Isopollen maps for Poland: 0-11000 years BP. New Phytologist, 94: 133-175.

Ralska-Jasiewiczowa, M., Latałowa, M., Wasylikowa, K., Tobolski, K., Madeyska, E., Wright, H.E. Jr., Turner, Ch., eds., 2004. Late Glacial and Holocene history of vegetation in Poland based on isopollen maps. W. Szafer Institute of Botany, Polish Academy of Sciences, Kraków.

Saarnisto, M., Eriksson, B., Hirvas, H., 1999. Tepsankumpu revisited - pollen evidence of stable Eemian climates in Finnish Lapland. Boreas, 28: 12-22.

Sauremo, M., 1940. Suomen luonnon kehitys jääkaudesta nykyaikaan (in Finnish). Werner Söderstrom Oy, Porvoo-Helsinki.

Seelos, K., Sirocko, F., 2007. Abrupt cooling events at the very end of the Last Interglacial. Developments in Quaternary Science, 7: 207-222.

Seidenkrantz, M.S., Knudsen, K.L., 1997. Eemian climatic and hydrographical instability on a marine shelf in Northern Denmark. Quaternary Research, 47: 218-234.

Seppä, H., MacDonald, G.M., Birks, H.J.B., Gervais, B.R., Snyder, J.A., 2008. Late-Quaternary summer temperature changes in the northern-European tree-line region. Quaternary Research, 69: 404-412.

Sirocko, F., Seelos, K., Schaber, K., Rein, B., Drehar, F., Diehl, M., Lehne, R., Jäger, K., Krbetschek, M., Degering, D., 2005. A late Eemian aridity pulse in Central Europe during the last glacial inception. Nature, 436: 833-836.

Stankowski, K., Bluszcz, A., Nita, M., 1999. Sites of upper Quaternary deposits at Mikorzyn and Sławoszewek in the light of geological studies, radiocarbon and luminescence datings and palynological analysis (in Polish with English summary). In: Geochronologia górnego czwartorzędu Polski w świetle datowania radioweglowego i luminescencyjnego (eds. A. Pazdur et al. ): 87-111. WIND J. Wojewoda, Wrocław.

Stankowski, W., Nita, M., 2004. Stratigraphy of Late Quaternary deposits and their neotectonic record in the Konin area, central Poland. Geological Quarterly, 48 (1): 23-34.

Stankowski, W., Nita, M., Pawłowski, D., 2003. Young Quaternary tectonic activity of Konin area (Middle Poland) (in Polish with English summary). Przegląd Geologiczny, 51: 49-54.

Striegler, U., 1986. Zum Eem-Interglazial von Klinge. In: Kurzreferate und Exkursionsführer "25 Jahre Arbeitskreis Quartärgeologie" der GGW vom 10. bis 13. Juli 1986 in Berlin (ed. A.G. Cepek): 39-40. Berlin.
Szafer, W., 1935. The significance of isopollen lines for the investigation of the geographical distribution of trees in the post-Glacial period. Bulletin de l'Académie Polonaise des Sciences et des Lettres Série B: Sciences Naturelles: 235-239.

Thouveny, N., de Beaulieu, J.-L., Bonifay, E., Creer, K.M., Guiot, J., Icole, M., Johnsen, S., Jouzel, J.. Reille, M., Williams, T., Williamson, D., 1994. Climate variations in Europe over the past 140 kye deduced from rock magnetism. Nature, 371: 503-506.

Tzedakis, P.C., Bennett, K.D., Magri, D., 1994. Climate and the pollen record. Nature,370: 513.

Velichko, A.A., Grichuk, V.P., Gurtovaya, Y.Y., Zelikson, E.M., Borisova, O.K., 1982. Palaeoclimatic reconstructions for the optimum of the Mikulino Interglacial in Europe. Izvestiya Akademii Nauk SSSR, Geographical Series 1: 15-27.

Velichko, A.A., Novenko, E.Yu., Pisareva, V.V., Zelikson, E.M. Boettger, T., Junge, F.W., 2005. Vegetation and climate changes during Eemian in Central and East Europe: comparative analysis of pollen data. Boreas, 34: 207-219.

Wacnik, A., Nalepka, D., Granoszewski, W., Walanus, A. Madeyska, E., Cywa, K., Szczepanek, K., Cieślak, E., 2015. Development of modern forest zones in the Beskid Niski Mts. and adjacent area (Western Carpathians) in the late Holocene: a palaeobotanical perspective. Quaternary International, doi.org/10.1016/j.quaint.2015.09.037.

Walanus, A., Nalepka, D., 1999. POLPAL. Program for counting pollen grains, diagrams plotting and numerical analysis. Acta Palaeobotanica, Suppl., 2: 659-661.

Wanner, H., Solomina, O., Grosjean, M., Ritz, S.P., Jetel, M., 2011. Structure and origin of Holocene cold events. Quaternary Science Reviews, 30: 3109-3123.

Webb, T. III, Bartlein P.J., Kutzbach, J.E., 1987. Climatic change in eastern North America during the past 18,000 years. Comparisons of pollen data with model results in North America and adjacent oceans during the Last Deglaciation. In: Geology of North America (eds. W.F. Ruddiman and H.E. Wright, Jr.): 447-462. Geological Society of America, Boulder.

Wegmüller, S., 1986. Recherches palynologiques sur les charbons feuilletés de la region de Gondiswil/Ufhusen (Plateau Suisse). Bulletinde l'Association française pour l'Etude du Quaternaire, 1/2: 29-34.

Welten, M., 1981. Gletscher und Vegetation im Lauf der letzten hunderttausend Jahre. Vorläufige Mitteilung. In: Gletscher- und Klimasymposium, 6-8 Oktober 1978 in Brig (ed. P. Kasser): 5-18. Jahrbuch der Schweizerischen Naturforschenden Gesellschaft, Wissenschaftlicher Teil.

Winter, H., Dobracka, E., Ciszek, D., 2008. Multiproxy studies of Eemian and early Vistulian sediments at Rzecino site (Łobez Upland, Western Pomerania Lakeland). Biuletyn Państwowego Instytutu Geologicznego, 428: 93-110.

Woillard, G., 1978. Grande Pile peat bog: a continuous pollen record for the last 140000 years. Quarternary Research, 9: 1-21.

Żarski, M., 1989. A new locality of Eemian Interglacial deposits near Dęblin (in Polish with English summary). Kwartalnik Geologiczny, 33 (2): 269-274. 